Article

\title{
Sustainability and the Tourism and Hospitality Workforce: A Thematic Analysis
}

\author{
Tom Baum ${ }^{1, *}$, Catherine Cheung ${ }^{2}$, Haiyan Kong ${ }^{3}$, Anna Kralj ${ }^{4}$, Shelagh Mooney ${ }^{5}$, Hải Nguyễn Thị Thanh ${ }^{6}$, \\ Sridar Ramachandran ${ }^{7}$, Marinela Dropulić Ružić ${ }^{8}$ and May Ling Siow ${ }^{9}$ \\ 1 Department of Human Resource Management, Strathclyde Business School, University of Strathclyde, \\ Glasgow G4 0QU, Scotland, UK \\ 2 School of Hotel and Tourism Management, The Hong Kong Polytechnic University, Hong Kong, China; \\ catherine.cheung@polyu.edu.hk \\ 3 Business School, Shandong University (Weihai), Jinan 250100, China; konghaiyan@sdu.edu.cn \\ 4 Griffith Business School, Griffith University, Gold Coast, QLD 4222, Australia; a.kralj@griffith.edu.au \\ 5 School of Hospitality, Tourism and Events, Auckland University of Technology, Auckland 1010, \\ New Zealand; shelagh.mooney@aut.ac.nz \\ 6 Vietnamese Institute for Human Rights, Ho Chi Minh National Academy of Politics, Hanoi, Vietnam; \\ thanhhai72@gmail.com \\ 7 Institute of Agricultural and Food Policy Studies, Universiti Putra Malaysia, Selangor 43400, Malaysia; \\ sridarupm@gmail.com \\ 8 Department of Tourism, Institute of Agriculture and Tourism, Poreč 52440, Croatia; marinela@iptpo.hr \\ 9 School of Management and Languages, Heriot Watt University, Kuala Lumpur, Putrajaya 62200, Malaysia; \\ mlsiow@gmail.com \\ * Correspondence: t.g.baum@strath.ac.uk; Tel.: +44-141-548-3954 \\ Academic Editor: Ian Patterson \\ Received: 14 June 2016; Accepted: 11 August 2016; Published: 17 August 2016
}

\begin{abstract}
This paper is about the position of workforce and employment considerations within the sustainable tourism narrative. The paper aims to address the relative neglect of this area within the discourse of sustainable tourism and highlights references to the workforce within the United Nations' 2030 Agenda for Sustainable Development. The discussion follows the emerging field of sustainable human resource management and the contribution that this can make to meeting both the UN Sustainable Development Goals and to enhancing the recognition of workforce and employment issues within the related debate in tourism. The body of the paper highlights examples of key dimensions of work and employment across varied tourism contexts, where sustainability is of increasing consequence and significance. The paper concludes by drawing together the implications of these "mini-cases" and locating them within key principles of the 2030 Agenda for Sustainable Development.
\end{abstract}

Keywords: sustainability; sustainable tourism; employment; workforce; education; gender; careers; social enterprise; human rights

\section{Introduction}

In 2015, the United Nations Sustainable Development Summit endorsed the 2030 Agenda for Sustainable Development, which highlights 17 Sustainable Development Goals (SDGs) designed to end poverty, fight inequality and injustice and tackle climate change by 2030 . While only the eighth goal (decent work and employment growth) specifically references the workplace and the environment of work, it is arguable that a significant number of the goals impinge in one way or another on the workforce and workplace in tourism. Thus, work, and indeed "decent work" as the International Labour Organisation (ILO) would style it, is at the heart of the sustainability debate. Nowhere is this 
more the case than in the context of sustainable development in tourism. Yet, it is our contention here that workforce and workplace considerations are widely neglected in the growing volume of debate relating to sustainable tourism. Our purpose is to illustrate that, due to this omission, decent work objectives continue to be unmet in the tourism sector. Insights and examples supporting our position (about significant, but unacknowledged, workforce themes) will be provided by tourism and hospitality academics actively researching in their area of expertise.

The starting point for this paper is to state that, despite this neglect, we advocate that consideration of employment and the tourism workforce is at the heart of the sustainable tourism narrative. It is both disappointing and inexplicable that few commentators, academic or practitioner, appear to recognize this omission. Indeed, the absence of workforce considerations from the mainstream sustainable-tourism narrative is one of the oddities in the overall debate addressing the area. In this paper, we will explore the positioning of workforce considerations within the discussion about sustainable tourism, or the absence thereof, and then seek to demonstrate the relevance of the sustainability narrative to a selection of workforce-related themes in the context of tourism and the United Nations Sustainable Development Agenda. By this means, we hope to illustrate the value of meeting specific goals and the wider principles enshrined within the agenda, to address the considerable challenges faced by tourism with respect to its workforce. We further suggest that serious consideration of the workforce should form the nexus of the entire sustainable tourism dialogue.

Some limitations to this discussion must be acknowledged at the onset. Tourism, as an industry, is characterized by diversity and constitutes a number of sub-sectors that include transport, accommodation, food service, retail, attractions, events and facilitation. Generalizing about the industry's workforce across sectors can be problematic for a wide range of reasons. Hospitality (accommodation and food service) is by some measure the largest and most ubiquitous component of tourism and is used as a proxy for the whole industry at times in this discussion. We are aware of the limitations that this imposes. Likewise, a limitation to our discussion here is the focus on the employee workforce to the neglect of self- and family employment in the small and micro business environment. Finally, the context of tourism employment varies greatly and is influenced by a wide range of economic, socio-cultural and political factors. These, in turn, inhibit generalization between, for example, less developed and developed economies.

\section{Sustainable Tourism and Employment}

The challenges that tourism faces in terms of employment, workforce or Human Resource Management (HRM) have been very well documented over an extended period (see, for example, [1-6]). These concerns are diverse, including inter alia: challenging working conditions; dirty and difficult work; low pay; lack of gender and minority opportunity; precarious, seasonal employment; low status of work; absence of clear career structures; and high labor turnover. The recurrent and prevailing themes, singularly and collectively, have been widely addressed at the policy and practical levels. The evidence, however, is of limited change in response to policies, initiatives and investment by the public and private sectors. Solnet et al. [7] highlight the failure of workforce-related policy over a ten-year period in both Australia and Scotland, highlighting that the issues identified did not change over the timeframe and that the proposed remedies remained static. Academic contributions to the narrative are also limited [6], aspiring to find 'solutions' to problems, rather than seeking or providing broader explanations for the social and economic drivers that underpin these challenges.

Therefore, how can sustainability, sustainable development and, critically, sustainable tourism contribute to addressing the issues that face employment in the tourism sector? Sustainability is a dominant theme in contemporary tourism discourse; Weaver [8] (p. 5), for example, is perceptive when he notes, "since the mid-1990s, discourses about the tourism sector have become increasingly dominated, at least rhetorically, by the ideas and ideals of sustainability". Sustainable tourism has become a focus of attention through a combination of factors. The growth in international tourism and an increased focus on environmentalism in society have led to enhanced awareness of the meaning 
of the principles of sustainability [9]. In this way, sustainability has become a dominant narrative within tourism policy development at all territorial levels, as noted by Torres-Delgado and Lopez Palomeque [10] (p. 1):

Institutional policies and initiatives have advanced gradually from an initial acceptance of sustainability in tourism associated almost exclusively with the conservation of the environment, to a more global concept which takes the balance between society, the environment and economy into account.

Edgell [11] (p. 27) sees policies that are underpinned by sustainability principles as limiting the "negative impacts on the social, economic, and environmental well-being of tourism destinations and local communities". Likewise, Maxim [12] (p. 38) emphasizes the increasing focus on sustainability, particularly in an urban context when explaining that "sustainable tourism is primarily associated with nature and environmental consequences, whereas in cities more visible are the economic and socio-cultural impacts of tourism". In the tourism sector, a number of sources (for example, [13-15]) suggests that industry advocates use the "jargon" of sustainability and community to strengthen their power bases and legitimize current unsustainable practices rather than genuinely working to achieve the benefits of a sustainable approach.

Regrettably, the dominant impression from the interrogation of the extensive sustainable tourism literature is that there is scant reference to the tourism workforce in this narrative. Admittedly, the criteria identified by the Global Sustainable Tourism Council [16] does include reference to the workforce by addressing the responsibilities of both destinations and hotels and tour operators, but this is limited in reference to the localization of opportunities and careers. The relative neglect of workforce considerations within the discussion relating to sustainable tourism policy in terms of and, indeed, within the debate in academic journals that focus on this theme is counter-intuitive, given that social, cultural and community-focused considerations are prominent in some (but not all) analyses of this area. This neglect is all the more challenging in light of the leadership provided by international agencies, notably the ILO's notion of decent work [17] and the clear guidance provided by Article 8 of the UN's 2030 Agenda for Sustainable Development, which advocates "full and productive employment and decent work for all" [18]. The emergence of sustainable HRM can be linked, at an organizational level, with growing interest in the full breadth of Corporate Social Responsibility (CSR) [19]. Sustainable HRM provides the basis upon which this neglect in tourism can be rectified. Predating the emergence of sustainable HRM as a serious field of study, Jithendran and Baum [20] (p. 405), used language that is very similar to that which has subsequently emerged in the mainstream when they argued:

Both from the development and preservation angle, HRD [Human Resource Development] holds the key to sustainability. Development requires a higher level of quality, and preservation requires attitudes, sensitivities and practices that are responsible towards and appropriate for the environment, local society, culture and economy.

Here, Jithendran and Baum [20] consider HRD in the tourism context to be the development of a professionally-trained and educated workforce, advocating a three-dimensional focus on tourism industry personnel, the host community and the tourists. This is in contrast to the more usual approach to HRM, which focuses on the organizational (macro) level and the effects of practices on individuals (micro).

Zaugg et al. [21] (p. 1) provide a definition of sustainable HRM as "long term socially and economically efficient recruitment, development, retainment and disemployment of employees". Figure 1 conceptualizes this definition as a model of sustainable HRM with a strong focus on the individual. Other authors tend to look at sustainability in terms of a local (destination), regional or national workforce. This broader approach is taken in the current consideration of the application of sustainability as a concept for the tourism workforce. 


\section{Culture • Attitudes $\bullet$ Values}

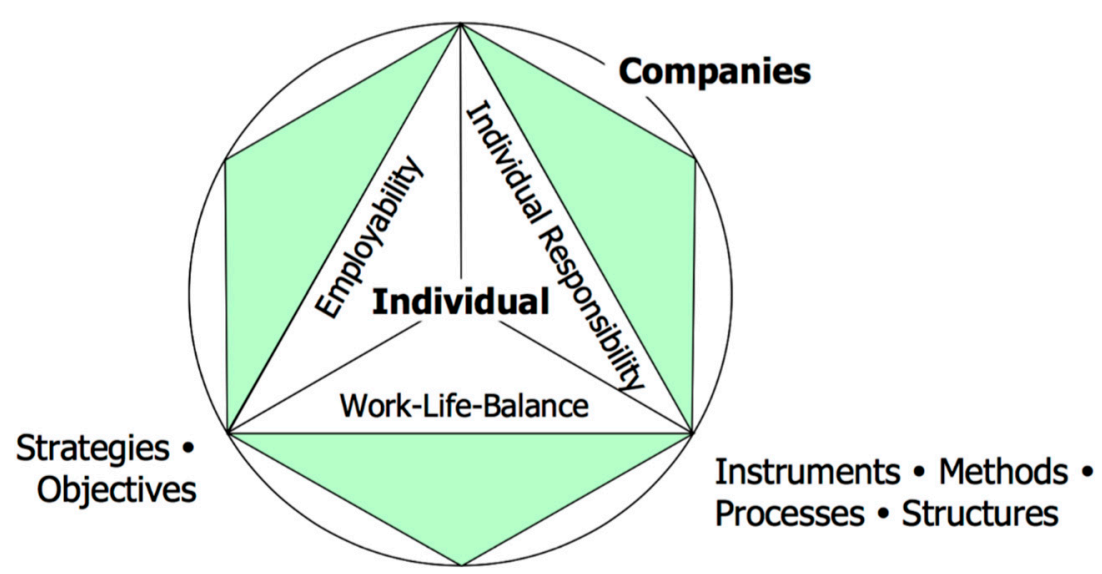

Figure 1. Model of sustainable human resource management [20] (p. 3).

Mazur [22] identifies three elements within sustainable HRM. These are: (1) a sustained supply of future employees; (2) workplaces that provide good treatment of employees, "decent work" in ILO terms; and (3) the engagement of employees in CSR practices, the latter based on Liebowitz's [23] (p. 50) notion that "if the management of a company hires capable people and treats them well, then those employees will be more inclined to take better care of the planet". This view is supported by other writers $[24,25]$ who clearly link the impact of HRM practices to environmental outcomes. Sustainable HRM, by definition, also acknowledges the possibility of unsustainable HRM [26] through practices that cannot be sustained at an organizational level and lead to burnout due to individual stress, other forms of illness or attrition. In the context of tourism, this inconvenient and therefore neglected dimension of the workforce is bundled by Baum $[27,28]$ as "the dark side of the coin" and is also addressed by Boardman et al. [29] in their analysis of decent work in the full tourism value chain.

Ehnert and Harry [19] (p. 223) identify two considerations in support of a sustainability approach to HRM. They are, firstly, the relationship between an organization and its economic and social environment; and secondly, how a company's internal HRM systems and processes accommodate the individual with respect to a range of themes, including "the observation of scarce human resources, of aging workforces and of increasing work-related health problems". Incorporating the wide range of good practices articulated by Liebowitz [23] in accommodating the needs of the individual within organizations "the argument is that fostering the sustainability of the HRM system itself becomes a 'survival strategy' for organisations dependent on high quality employees" [19] (p. 223). This is a perception of HRM practices from which tourism in many contexts, worldwide, could undoubtedly benefit.

The preceding, necessarily brief, review indicates that, in order to achieve sustainable HRM, a sustainable workforce must be developed by tourism operators and host communities. What, then, does sustainable practice in the area of tourism employment and the sector's workforce look like in practice? Many of the challenges, or the dark side of tourism employment, addressed above represent practice that is not sustainable, including as examples:

- short-termism as a result of stochastic demand and deficient business planning;

- the misperception that skills are not required for many lower level hospitality jobs, thus denying workers their professional identity;

- widespread employment of labor, at all skills levels, that is not from the community or even country where the operations are located, denying opportunity to the local labor market;

- $\quad$ wide-term perception of employees as a cost and not as an asset to the business; 
- poor working conditions and relatively poor pay, acting as a disincentive to either join or remain in the industry;

- dominance of small businesses (both in the formal and informal sectors) that limit career progression opportunities;

- limited engagement with diversity issues, meaning women and minorities do not have opportunities for progression; and

- human rights' abuses through extensive use of child labor and working conditions that deny family rights.

The problem or challenge highlighted by this paper is that there appears to be a lack of planning and engagement on the part of the tourism academy, tourism organizations and host communities to commit to the development of a sustainable tourism workforce that will enjoy the benefits associated with the UN's ideals of decent work. Box 1 represent the goals that are most closely affiliated with the tourism context. If the examples given in the previous paragraph represent unsustainable workforce characteristics or widespread and entrenched practices in tourism, the corollary is represented by practices that do focus on "decent work", do provide opportunity on an equal basis for all members of the community, are progressive and developmental and compete successfully for skills with other sectors of the local, national and international economy. Such criteria are, of course, ambitious and aspirational, but this notwithstanding, they do represent a vision of work in tourism that is every bit as laudable and plausible as that represented by those advocating responsibility through tourism for the natural and cultural environment.

Box 1. United Nations Sustainable Development Agenda goals supported by tourism employment and tourism and discussed in this paper.

\section{United Nations Sustainable Development Agenda Goals}

Goal 1: to end poverty in all its forms and everywhere.

Goal 3: to ensure healthy lives and well-being for all at all ages.

Goal 4: to ensure inclusive and equitable quality education and promote lifelong learning opportunities for all.

Goal 5: to achieve gender equality and empower all women and girls.

Goal 8: to promote sustained, inclusive and sustainable economic growth, full and productive employment and decent work.

Goal 10: to reduce inequality within and among countries.

Goal 16: to promote peaceful and inclusive societies for sustainable development, provide access to justice for all and build effective, accountable and inclusive institutions at all levels.

The following section will discuss international and local perspectives on important, but somewhat neglected themes in the sustainable tourism debate, provided by researchers who have explored issues that would benefit from greater tourism academy engagement when considering how to advance sustainability ideals. Following these macro/meso insights, links will be made with specific UN development goals to demonstrate that HR development in the tourism sector is an objective that has yet to be achieved.

\section{Applying Sustainability to the Workforce Domain in Tourism}

The workforce or HRM in the context of tourism is multi-faceted and complex. Baum et al. [6] classify workforce research in tourism into micro (the individual), meso (the organization) and macro (the destination or beyond), acknowledging that some overlap exists between the three, especially between micro and meso. Attempting to address all of the diverse themes that are commonly 'bundled' under these labels in the context of this paper would lead to broad generalizations that would not do the topic justice. Therefore, this paper seeks to dip into selected themes in rather greater depth, 
acknowledging the randomness and subjectivity in the selection of those themes that are covered here. However, the examples given show that at macro, meso and micro levels of tourism employment across many different contexts, there are endemic and systematic failures to meet or even consider sustainable HRM or HRM development principles.

\subsection{Gender, Employment and Sustainability in Tourism}

Gender is a major workforce issue in all countries and cultures and impinges on all levels (micro, meso and macro) identified above. Here, the discussion focuses on the New Zealand context, but the issues raised in terms of sustainability apply equally in virtually every other jurisdiction. Globally, women working in the tourism sector are disadvantaged compared to men, earning less and concentrated in lower quality jobs [30-32]. In New Zealand, for example, in 2013, women in the female-dominated (62.4\%) housekeeping and restaurant services sector not only earned the lowest income (median) of all occupations, but their income comprised $84 \%$ of the income of men also employed in the sector [33]. The contributors to gender inequality are multifaceted and complex; however, they include restricted hours due to women's caregiving responsibilities, occupational sex stereotyping, occupational segregation, discriminatory promotional practices and a lack of flexible workplace arrangements, all of which limit women's employment choices. Critical gender scholars, such as Holvino [34], observe that it is not possible to separate gender from color when considering women's participation in employment. This intersection is visible in New Zealand, where a disproportionately high number of Māori and Pacifica women occupy the lowest strata of service sector jobs [35] and where, in hospitality, European men are more likely to hold senior leadership positions [36,37]. Therefore, being a woman and/or belonging to a minority ethnicity group appears to negatively impact women's career possibilities and promotional processes, and stereotypical views on suitable roles penalize women and privilege men in the sector [38].

When revisiting the "glass elevator" that advantages men in feminized employment sectors after 20 years, Williams [39] argues that feminist activists must move beyond the focus on women and protest against the profoundly negative impact of lowly-paid precarious work, not just on women, but on families. The New Zealand tourism sector could benefit from such activism as it employs one in sixteen people [40]. Here, precarious work practices have become the norm, as in Australia [41]. In real terms, hospitality hourly pay rates in New Zealand have dropped significantly over the years, compared to other sectors of the economy, with many workers employed at the legal minimum wage rate [42]. Economists have calculated that workers on the current minimum wage would need to earn $21 \%$ more per hour to reach the "living wage" threshold that would enable them to maintain an acceptable standard of living [43]. Hence, long working days spread over multiple employers are required by casualized hospitality workers to support their families. Although abuse of migrant workers (many of whom are women) is not identified as problematic by tourism employers [40], recent high-profile employment law breaches highlight the widespread exploitation of migrants and international students by employers in the sector [44]; in some instances, workers were paid $80 \%$ less than the minimum wage over an extended period of time.

Therefore, the fact that women, especially women of minority ethnicity, hold the majority of the poor-quality jobs in the sector should not be perceived as a "women's problem" and symptomatic of their disadvantage in the labor market. There are wider societal ramifications; for example, possibly due to the structural advantage of $24 / 7$ employment opportunities in the sector, the retail, accommodation and food services sector is the largest provider of jobs for solo mothers in New Zealand [45]. However, because the majority of jobs are held by non-professional and non-managerial workers on a temporary basis, financial penalties are not confined to the individual, but disadvantage the wider community and the next generation. Additionally, the negative side effects of poor-quality work on workers are well documented [46], including a prevalence of stress, high accident rates and poor mental health outcomes for workers. As with low pay rates, these poor health outcomes also have wider societal costs that extend beyond the individual concerned. 
Somewhat ironically, the structural features of the industry are more than capable of delivering the elements identified by tourism researchers that increase workers' wellbeing: strong social connectivity; interesting variety of work; flexible work options; and development opportunities [47-49]. Yet, such opportunities are frequently inaccessible to the many workers in casual work arrangements. A further deficiency is that more enlightened human resource management strategies, including stable and flexible work practices that reduce work/family conflict, are not consistently available across the sector [50]. Perhaps unsurprisingly, young people in New Zealand appear to be turning away from careers in the industry. The ultimate consequence of the failure to provide decent work has possibly resulted in the labor shortages experienced by prime tourism destinations, such as Queenstown, negatively affecting New Zealand's image as a quality tourist destination. Tourism employers, when surveyed about the potential reasons for the lack of skilled workers, believed a general lack of knowledge about career paths available in the sector was a contributory factor [43]. Yet, employment statistics suggest that the majority of women in tourism are employed in what appear to be low-quality, minimum wage jobs rather than in fulfilling careers or "full and productive employment and decent work for all" [49]. Therefore, it can be seen that in order to build a sustainable workforce, employers must bridge what appears to be a major gap between perceptions of tourism employment and careers in the sector. Yet, questions about careers in tourism are not confined to New Zealand, as the next section indicates.

\subsection{Mobilities/Migration and Sustainability in Tourism}

The UN's Sustainable Development Goal No. 8 [18] is centered upon economic growth that creates full, productive and decent work for all. Yet, as Urry [51] points out, economic development requires people to move to where employment has been created. In tourism, studies of mobility often focus on the movement of the tourist and statistics abound demonstrating sustained (past and future) growth in tourist arrivals. However, understanding of the issues related to the mobility of workers to meet the increased demand is less progressed [52,53].

Considerations related to the sustainability implications of worker mobility and migration are highlighted even less often. Indeed, a recent special issue on "sustainable mobility" in the Journal of Sustainable Tourism [54] spoke almost exclusively to the transportation aspects on the demand side of tourism and largely ignored the mobility for employment issues related to the supply side of tourism. Dredge and Jamal [55] depicted an Australian case of the impact of mobility on sustainable tourism governance at a local level, although the case was more broadly focused on societal impacts than purely on the workforce.

Recent forecasts demonstrate the global mobilities of tourists and workers in action. From 2010 to 2030, tourist arrivals are expected to grow by an annual average of $3.3 \%$, up to 1.8 billion in absolute terms [56]. Over the same period and beyond, forecasts for mass urbanization show $66 \%$ of the population living in urban areas by 2050, up from $54 \%$ currently [57]. Concomitantly, the trend, which some argue began with the Industrial Revolution [58], sees more workers moving to the urban "core", while growing numbers of tourists are moving to the "pleasure periphery" [59]. In a future scenario model, Robinson et al. [53] used a core-periphery conceptualization to highlight the probable divergence between tourist and worker mobilities in the Asia-Pacific region in 2030 and the associated challenges. Others have also highlighted that the global movement of workers is diametrically opposed to the movement of tourists (e.g., [60-62]). A special issue of the Scandinavian Journal of Hospitality and Tourism [63] highlighted the workforce amongst mobility issues related to tourism in sparsely-populated areas.

In relation to Goal No. 8, a divergence of tourist and worker mobilities poses two main questions. First, how sustainable is the pull of workers to the core, and does it produce "decent work for all"? Hospitality jobs are not renowned for providing "meaningful" work and are often viewed as servile occupations [64] with Orwellian stigmas attached [6]. While migrants to urban areas are attracted to the opportunities for business and employment, as well as access to improved healthcare, sanitation, 
education and working conditions, not all migrants will benefit from the opportunities or get the necessary access $[65,66]$. As urbanization progresses around the globe, sustainable development challenges will center on the cities [57].

The second question is, how sustainable is the mobility divergence for tourism and hospitality operators at the periphery, in terms of workforce stability and quality service delivery? An appropriately-skilled labor supply in rural and remote areas is already a challenge for tourism operators [67,68]. Projected trends will only exacerbate the situation further $[69,70]$. Without a resident supply of adequate labor, tourism in peripheral locations can sometimes have a "displacement effect" on local employment [71]. In the spirit of Goal No. 8, displacing local employment is neither "inclusive" nor "for all". Seasonality may even render "full and productive employment" at the periphery unsustainable.

The impact of skilled labor accumulating at the core, while demand for skilled labor increases at the periphery, presents quite a challenge for tourism policy-makers and planners. To tackle the (limited scope of) issues raised here, sustainable tourism workforce mobility and migration will require coordinated and integrated policy and planning approaches at the local, regional, national and even transnational levels. Vocational career mobility and migration choices are further influenced by individuals' life stage and economic aspirations for themselves and their families. Age is not a fixed chorographical dimension but a dynamic factor that influences employment in individual societies and sectors. The wider implications surrounding a predominantly older or younger tourism workforce are significant when considering sustainable tourism employment.

\subsection{Generational Perspectives on Employment and Sustainability in Tourism}

There is a growing hospitality management literature focused on exploring generational differences in terms of work values, job satisfaction, work-life balance, work engagement, job burnout and intention to leave the organizations. Based on the birth cohort perspective, differences among three age cohorts ("Baby Boomers": 1945-1964; “Gen X": 1965-1980; “Gen Y/Gen Me/Nexters/Millenialls": >1980) have been explored from: (a) frontline and service contact employee perspectives [72-74]; (b) managerial perspectives [75]; and (c) the perspectives of both groups of employees' and managers [76-81] (except housekeeping [82]). Students' perspectives on work values and their career expectations have been explored in terms of understanding the entrants' (Gen Y) ways of thinking on arrival in the tourism and hospitality labor market (e.g., [83-91]).

According to studies that are focused on the determination of differences on work values within the hospitality context, the biggest differences were reported in their attitudes towards authority and work-life balance $[73,75-77,81,82]$. For Gen $Y$, in comparison to their older colleagues, work environment and economic return are very important issues. Kim et al. [92] found that Generation $Y$ hospitality employees are more likely to incorporate environmental issues into their pro-environmental behaviors and to embrace environmental initiatives than Gen X employees. Although the majority of studies indicate that this younger generation reported lower scores on job satisfaction, work engagement, commitment and greater intention to quit $[71,74,76,79,82]$, researchers Inelmen, Zeytinoglu and Uygur [93] found that Gen Y employees were more satisfied than their older colleagues and equally committed. The results of Maier's [80] study provides contradictory evidence: a lower level of job satisfaction for younger generations and the greatest intention to leave in Baby Boomers. These mixed findings must be interpreted contextually and with caution because, besides their cross-sectional nature (both survey and interview-based), different work-value items were used to compare different ranges of generations from different country and hospitality settings (Australia, Netherlands, Cyprus and (the domination of) the USA). Stronger theoretical grounding, qualitative understanding of the phenomenon, greater consideration of the historical and social context of the nation in focus and greater methodological rigor $[94,95]$ are the key guidelines for future research on generational differences generally, which is particularly relevant for sectors with major employee retention issues, such as hospitality. 
In terms of sustainability, the tourism industry has typically been successful in hiring employees, but not so fortunate in retaining them [96]. Therefore, in the context of the sustainable management of youthful generations in this work-intensive environment, the biggest challenges are related to the management of the turnover culture; in other words, the management of young workers' intention to quit, as well as raising the level of their organizational commitment and occupational commitment. Their desire for an exciting and challenging career [97], as well as their even higher aspirations for long-term careers are objectives that the hospitality industry can do more to meet [86]. Fulfilling these expectations remains an uncompleted task for HRM in the tourism industry, which is still searching for new and innovative ways to appease the perceived high demands and expectations of Gen Y [40]. The key word in the management of younger generations in tourism is flexibility, especially in an era of new career patterns: the "butterfly" progression whereby individuals "flutter" from, and within, sectors and job types [98]. In terms of knowledge exchange and the mentoring process, the key word in the management of older generations in tourism concerns the notion of an alliance (with youth generations). The idea of an alliance between generations is particularly relevant when considering tourism education (which will be addressed at a later stage in this article). The notion of alliance must include protection of minors, who are vulnerable to exploitation in certain tourism sectors, such as homestays.

\subsection{Career Competencies of Employees in Tourism}

Attracting and retaining qualified talent is currently a major issue in the hospitality industry. Career management aims to achieve gradual improvement by operating in harmony with efforts to enhance employees' career competency. In this sense, career management strategies represent a sustainable approach to the development and maintenance of key staff members within tourism businesses [99]. Addressing employees' lives in this way does not only address the needs of the individual, but contributes to the wider engagement of their families and social networks, potentially delivering wider benefits to individual businesses and the industry in general $[100,101]$.

In recent years, a growing number of studies, therefore, have been conducted in order to explore the determinants of career competencies from different perspectives [99,102]. It has been found that perceived hotel career management and career commitment contribute positively to career competencies. The findings further suggest that organizations and individuals have respective obligations in the career management of employees. From the family perspective, there is a positive relationship between work-family-supportive supervisors and career competencies. In addition, experiential learning and learning satisfaction are also important predictors of career competencies [103].

In terms of the outcomes of career competencies, career competencies are positively related to career satisfaction, job involvement and job satisfaction. Furthermore, career competency mediates the relationships between three dimensions of perceived hotel career management and career satisfaction. These are all strong contributors to the attainment of a sustainable approach to individual career management and the wider challenge of reducing staff turnover in tourism organizations. However, any discussion about career management and turnover in tourism organizations in specific locations must be seen within the contemporary understandings of vocational mobility and global migration patterns. Tourism educators play an important role in preparing students for an increasingly global career; however, imparting specific "employability"-related skills and competencies is not enough by itself to produce responsible citizens of the world. Bratton and Gold [104] (p. 504) argue that HRM academics have the moral duty of teaching upcoming generations to "better address the competing demands for profit, social justice and environmental protection" in ways that are critically reflexive and contextually sensitive. The tourism sector, especially, would benefit from such an approach. 


\subsection{Tourism Education and Sustainability}

"Sustainability" is a term that has been interpreted in the past as environmental issues that influence economic growth. Recent understandings of sustainability include sociocultural factors [105]. Sustainability involves the integration of social and environmental factors with economic considerations; it is an extension of the "triple bottom line" measurement of sustainability performance [106]. There is some evidence that the business sector has begun to see the importance of sustainability-related issues, and the academic community has advocated offering curricula that teach students to make business and financial decisions that consider social and environmental responsibilities, as well as economic concerns $[107,108]$. Sustainability education therefore incorporates three major dimensions: social, environmental and economic [109,110].

In tourism education, educators have a vital role to play in educating future leaders who can promote sustainability. Wade [111] noted the importance of preparing students to deal with the complexities of sustainability within the hospitality and tourism industry. Similarly, Deale and Barber [112] advocated two major reasons for hospitality educators to teach sustainability in tertiary education: the significance of sustainability to the hospitality industry; as well as the need to produce graduates who have the knowledge of sustainability concepts, and their applications, to meet the challenges of the workplace.

To understand how important sustainability education in hospitality programs is for the three stakeholder groups of hospitality students, industry professionals and educators, Deale and Barber [112] found differences among the three groups in environmental attitudes and behaviors, as well as in beliefs about what and how sustainability topics should be taught. Nevertheless, sustainability was perceived as crucial in education by the three stakeholder groups. Another U.S. study that particularly examined the perspectives of hospitality industry managers indicated that hospitality sustainability education should be delivered in a more comprehensive way. The focus should go beyond a single dimension of sustainability, i.e., protecting the environment; instead, it must consider realistic business contexts, in order to effectively apply sustainability concepts to operations, finance and socio-cultural management [113].

The benefits to society and the national economy of effective hospitality and tourism sustainability education include: increasing employment; the preservation of cultural and natural resources; and the positive economic impact of increasing access to outside resources that benefit a community [114]. It is important to find out how sustainability concepts and practices can be embedded in teaching and research in hospitality higher education. The following are a few recommendations as to its implementation:

- Use of experiential learning; e.g., organizing field trips for tourism students studying ecotourism to examine and study sustainability issues on site [115].

- Use social media for sustainability learning; e.g., Facebook has been used to engage students in sustainability and tourism [116].

- Promote group discussions, problem-based learning, service learning, critical thinking through case studies and collaborative learning [117].

- Further research on the use of technology in sustainable education for the hospitality industry; e.g., power management systems and green procurement programs for hotel chains, waste reduction and recycling for the restaurant industry, etc. [118].

It is also important to stress the importance of sustainability in this contemporary domain of life-long education for workers and for the older generations who are reappraising their relationship to the workplace at a time of uncertain futures over issues, such as pensions. Two-way transfer of knowledge is an important underpinning for sustainable, life-long education, so the importance of what might be called the 'inter-generational alliance' between youth and older people in learning will more and more be in focus. While global perspectives and universal issues are important in 
this discussion on tourism employment, it is nonetheless essential to consider how local context and attitudes influence employment practices and individual outcomes.

\subsection{Tourism Social Enterprise and Sustainable Human Resource Management Issues in Peripheral Areas}

A tourism social enterprise ("socent"), such as a home-stay operation, which is a non-traditional economic activity for communities in geographically-remote or peripheral regions, provides both benefits and challenges [119-123]. Human resources management prevails as a core issue for communities delivering tourism services and the National Tourism Organizations (NTOs) that are responsible for managing tourists' expectations [124].

Geographically, being far from state of the art infrastructure, the notion of whether rural resources can truly become sustainable tourism capital, able to deliver satisfactory service to international tourists, remains a question mark. Rural resources provide the cultural and natural authenticity that fulfils the tourists' gaze; however, do rural communities have the capacity to handle and manage the demands of tourists? Frequently, due to financial constraints and lack of policy implementation and enforcement, the communities opt for shortcuts that do not comply with the standards set by the national tourism organization. Evidence from South East Asian peripheral regions shows that communities ignore the licensing requirements set by their respective NTOs [125]. For instance, the use of fashionable words like "Homestay" in their socent advertisements seems acceptable for some communities, even though this does not involve abiding with licensing requirements. Hence, employing unskilled foreign labor or "sea gypsies" without legal documentation becomes an acceptable norm amongst these communities [126,127]. The reasons for the lack of host involvement as service providers are due to the seasonal nature of the tourism product and religious beliefs that deter a certain group from being directly involved in the tourism scene.

The main motivation for community enterprises to employ these marginalized workforces is low wages, and without legal documentation, the employer can evade providing employment benefits. The other, more serious concern is the employment of child labor. As some children without documentation do not have access to education and health benefits, socent owners take this as an opportunity to recruit them as menial workers. Who is to be blamed for these HRM challenges? Are the market forces to be blamed? Are the government agencies to be blamed? Or are the tourists to be blamed? In a capitalist market, more money means a better livelihood for the communities.

The government agencies involved have drawn up policy statements for sustainability and the betterment of livelihoods with the aim of becoming a high income-earning nation. Training and development is at the heart of this investment [128,129], and the tourists, whether responsible or irresponsible, consume products that may be unethical in nature. If tourism is good for peripheral regions, then what is required are enablers that help in achieving rural development goals without compromising social responsibility.

Social capital enablers that consist of bonding, bridging and linking can assist in addressing the HRM issues in peripheral regions. Establishment of a cooperative will enhance the bonding, bridging and linking of community members, which will translate into a sense of ownership of their rural resources. The injection of education and awareness into religious congregation centers, which affirms that tourism is a legal business that need not be feared, could be incorporated at the bonding stage. Bonding helps build trust among community members and the bridging enabler could include the involvement of community members in decision-making roles, as well as holding a certain responsible membership position within their respective communities. The bridging stage will enhance and empower the involvement of community members in responsible decision-making. The linking component is crucial, as it creates a platform between community members and authorities, such as the local council, state and federal agencies, where a healthy relationship can resolve issues pertaining to responsible human resources management for tourism in peripheral areas. Hence, a tourism socent in peripheral regions is a positive contribution to the development of sustainability within the destination. Essentially, it needs human resource enablers (attracting the right people, training and development) 
to achieve these sustainability goals. A core element of sustainable human resource practices in all national contexts is the incorporation of human rights principles.

\subsection{Sustainable Human Resource Management in Tourism: A Human Rights Issue}

Human rights issues, in relation to the tourism and hospitality workforce, can broadly be categorized into a number of key areas, all of which relate to sustainability and the development of sustainable tourism at an organizational and destination level.

Economic development, specifically in tourism, may impinge on the land, water and wider rights of communities and families with respect to economic activity (agriculture, fishing, other), employment, education, health, recreation and environmental concerns (access to water, sanitation and waste disposal). Land rights issues have been highlighted by a range of cases linked to different sectors of tourism; for example, hotels in the case of Myanmar [130] and mega-events [131].

The absence of "decent work" (conditions, hours, shifts, remuneration) for many adults working in travel and tourism and the impact that has on the lives of families and communities is a direct human rights concern. As already noted, workplace issues in tourism are well documented and highlight, inter alia, seasonal work, women's rights and gender opportunity, migrant work and ethnic ghettoization, fair wages, long working hours, low investment in qualifications and few opportunities to develop skills, inability to join trade unions and the displacement of traditional employment to benefit from the development of tourism. Tourism workers often do not earn a living wage and are dependent on tips and service charges. They frequently have temporary contracts or none at all, work long hours with split shifts and are employed in low-skilled areas, such as service and housekeeping (see, for example, [4,132,133]).

Child labor that contravenes legal provisions, with respect to the age of the child and the nature of the work that is required, may include: working under the legal age for the sector and the type of work; hazardous work; and work within family enterprises. The ILO [134,135] estimates that 13-19 million children and young people below 18 years of age (10-15 percent of all employees in tourism) are employed in the travel and tourism industry worldwide. Many boys and girls below 12 years of age are engaged in small business activities related to hotels and restaurants, the entertainment sector or the souvenir trade, often as porters or street or beach vendors. According to the ILO, they are frequently subjected to harsh working and employment conditions. Children of school age frequently work in family travel and tourism organizations in ways and at times that impact on their school learning in whole or in part [136]. While the elimination of child labor remains a highly desirable outcome, Admassie [137] provides a cogent argument for change to be gradual in order not to threaten livelihoods in subsistence-based rural economies, proposing instead a move towards combined work and school attendance in the short-to-medium term. This model has the potential to be workable and realistic in the context of rural travel and tourism, where the demand for labor is frequently seasonal or out of formal school hours.

Certainly, non-economic work in the home enables parents to meet working obligations in travel and tourism [138]. Although more boys than girls work, such work affects girls disproportionately and can seriously impact on their learning opportunities at school. Very few children actually get paid for the work they do, and the ILO estimates that, globally, over 100 million girls (46\%) are involved in child labor [139]. Generally, girls start such work at a younger age than boys [140]; their position is very vulnerable, and the majority of them work in agriculture and domestic service. The work is often invisible, hidden away from the public eye and very hard for authorities to check on or regulate.

Commercial sexual exploitation and trafficking of children within the context of tourism and the role of children as sex workers have led to justifiably strong responses from governments, international agencies, such as UNICEF, and NGOs, including ECPAT (originally End Child Prostitution in Asian Tourism but now known internationally by its acronym) and Equations. Serious consideration of this aspect of child rights in travel and tourism is by no means new, and the debate gained particular momentum in work dating from the 1990s: Ireland [141], Beauttah, Rhova and Waweru [142], 
Black [143], ECPAT [144], Gust [145] and Plüss [146] are examples. As a response, The Code (short for "The Code of Conduct for the Protection of Children from Sexual Exploitation in Travel and Tourism") provides an internationally-recognized protocol, which has been adopted by a wide range of companies as a means of addressing this issue. Sexual exploitation and trafficking of children undoubtedly are the dominant themes in the literature and are widely addressed in the context of social sustainability, tourism development in less-developed countries and sex tourism.

\section{Conclusions}

It is apparent when reviewing the case examples of the interface between sustainable HRM principles and tourism employment practices (and the lack of enlightened tourism HRM) that fractures, in some cases chasms, exist between what may be desirable and what is actually practiced. The previous discussion highlights complex issues occurring at the macro, meso and micro levels that indicate that the tourism and hospitality workforce is not sustainable. A common thread throughout is the failure to acknowledge or implement HRD strategies at macro and meso levels. The overall picture leaves great scope for improvement.

Table 1 summarizes the seven themes explored in this discussion and whether the implications or "main effects" of the themes emerge at societal, organizational or individual level. The themes are then cross-referenced with each goal, with a broad indication of whether the goal has been met/not met or could be met in the future.

Implementing effective sustainability policies and practice for HRM is clearly complex and it is arguable that the neglect of this area is widespread across most sectors of the economy and in most countries. Nowhere is this more the case than in the context of tourism. Therefore, the incorporation of core sustainability principles must address concerns, such as those that have been raised in this article, across a spectrum of areas within and beyond tourism. This paper endeavors to demonstrate that the tourism sector must commit to the overarching aim of sustainable employment for all tourism workers, which enshrines the protection of basic human rights, especially for women, children, minorities and those who are less privileged in society. Such sustainability must, at its heart, address the goals set out in the UN's [18] Agenda for Sustainable Development. In particular, the dimensions of the case examples presented here resonate with seven of the goals outlined in Section 2, both directly and indirectly.

There are clear conclusions that may be drawn from the outline of the relationships between the discussion themes and the UN goals. Table 1 highlights the extent to which customary tourism employment practices, as indicated in the case examples, fail to meet the designated UN agenda goals. Clearly, Goal 8, to promote sustained, inclusive and sustainable economic growth, full and productive employment and decent work, is at the heart of sustainable HRM and has particular relevance to tourism and the range of challenging employment opportunities within the sector. However, the wider goals (Goal 1, to end poverty in all its forms and everywhere; Goal 3, to ensure healthy lives and well-being for all at all ages; and Goal 16, to promote peaceful and inclusive societies for sustainable development) address the opportunities that tourism employment, located in major conurbations and peripheral communities across the globe, affords. Gender opportunity (Goal 5) is recognized as a key strategic imperative for tourism if it is to maximize the talent potential of the sector and contribute to poverty alleviation, especially in rural communities (Goal 1) and to reduce inequality within and among countries (Goal 10). Finally, the table clearly indicates that the provision of educational opportunity, for the increasingly demanding generations of new entrants and the subsequent career development for those working in tourism, is central to enhancing the image of the tourism industry as an employer (Goal 4). 
Table 1. Summary of whether customary tourism employment practices at micro (individual), meso (institutional) and macro (organizational) levels meet United Nations Agenda Goals.

\begin{tabular}{|c|c|c|c|c|c|c|c|}
\hline $\begin{array}{c}\text { UN Sustainable } \\
\text { Development Agenda Goal }\end{array}$ & Theme 1: & Theme 2: & Theme 3: & Theme 4: & Theme 5: & Theme 6: & Theme 7: \\
\hline & $\begin{array}{l}\text { Gendered aspects of } \\
\text { tourism employment } \\
\text { (micro/meso/macro) }\end{array}$ & $\begin{array}{c}\text { Tourism } \\
\text { mobilities/migration } \\
\text { planning (meso/macro) }\end{array}$ & $\begin{array}{l}\text { Generational } \\
\text { perspectives on tourism } \\
\text { employment } \\
\text { (meso/macro) }\end{array}$ & $\begin{array}{l}\text { Career competencies } \\
\text { development needs } \\
\text { (micro/meso/macro) }\end{array}$ & $\begin{array}{l}\text { Tourism education } \\
\text { and sustainability } \\
\text { (meso/macro/micro) }\end{array}$ & $\begin{array}{c}\text { Local tourism social } \\
\text { enterprise. } \\
\text { Discrepancies between } \\
\text { policy at institutional } \\
\text { level and local practice } \\
\text { (meso/macro) }\end{array}$ & $\begin{array}{c}\text { Human rights in } \\
\text { global tourism } \\
\text { development and } \\
\text { employment } \\
\text { context } \\
\text { (micro/meso/macro) }\end{array}$ \\
\hline \multirow{2}{*}{$\begin{array}{l}\text { Goal 1: to end poverty in all its forms } \\
\text { and everywhere. }\end{array}$} & \multirow{2}{*}{ Not met } & \multirow{2}{*}{ Not met } & Not met & \multirow{2}{*}{ Not met } & \multirow{2}{*}{ Can contribute } & Not met & \multirow{2}{*}{ Not met } \\
\hline & & & Can contribute & & & Can contribute & \\
\hline \multirow{2}{*}{$\begin{array}{l}\text { Goal 3: to ensure healthy lives and } \\
\text { well-being for all at all ages. }\end{array}$} & \multirow{2}{*}{ Not met } & \multirow{2}{*}{ Not met } & Not met & \multirow{2}{*}{$\begin{array}{l}\text { Met to some extent } \\
\text { in hotel sector }\end{array}$} & \multirow{2}{*}{ Can contribute } & Not met & \multirow{2}{*}{ Not met } \\
\hline & & & Can contribute & & & Can contribute & \\
\hline \multirow{2}{*}{$\begin{array}{l}\text { Goal 4: to ensure inclusive and } \\
\text { equitable quality education and } \\
\text { promote lifelong learning } \\
\text { opportunities for all. }\end{array}$} & \multirow[b]{2}{*}{ Not met } & \multirow{2}{*}{ Not met } & Not met & \multirow{2}{*}{$\begin{array}{l}\text { Met to some extent } \\
\text { in hotel sector }\end{array}$} & \multirow{2}{*}{ Can contribute } & Not met & \multirow{2}{*}{ Not met } \\
\hline & & & Can contribute & & & Can contribute & \\
\hline \multirow{2}{*}{$\begin{array}{l}\text { Goal 5: to achieve gender equality } \\
\text { and empower all women and girls. }\end{array}$} & \multirow{2}{*}{ Not met } & \multirow{2}{*}{ Not met } & Not met & \multirow{2}{*}{ Not met } & \multirow{2}{*}{ Can contribute } & Not met & \multirow{2}{*}{ Not met } \\
\hline & & & Can contribute & & & Can contribute & \\
\hline \multirow{2}{*}{$\begin{array}{l}\text { Goal 8: to promote sustained, } \\
\text { inclusive and sustainable economic } \\
\text { growth, full and productive } \\
\text { employment and decent work. }\end{array}$} & \multirow[t]{2}{*}{ Not met } & \multirow[t]{2}{*}{ Not met } & Not met & \multirow[t]{2}{*}{ Not met } & \multirow[t]{2}{*}{ Can contribute } & Not met & \multirow[t]{2}{*}{ Not met } \\
\hline & & & Can contribute & & & Can contribute & \\
\hline \multirow{2}{*}{$\begin{array}{l}\text { Goal 10: to reduce inequality within } \\
\text { and among countries. }\end{array}$} & \multirow{2}{*}{ Not met } & \multirow{2}{*}{ Not met } & Not met & \multirow{2}{*}{ Not met } & \multirow{2}{*}{ Can contribute } & Not met & \multirow{2}{*}{ Not met } \\
\hline & & & Can contribute & & & Can contribute & \\
\hline \multirow{2}{*}{$\begin{array}{l}\text { Goal 16: to promote peaceful and } \\
\text { inclusive societies for sustainable } \\
\text { development, provide access to } \\
\text { justice for all and build effective, } \\
\text { accountable and inclusive institutions } \\
\text { at all levels. }\end{array}$} & & & Not met & & & & \\
\hline & Not met & Not met & Can contribute & Not met & Can contribute & Can contribute & Not met \\
\hline
\end{tabular}


In conclusion, therefore, we argue that in sustainability terms, the selected tourism workplace and employment-related themes in this paper speak directly to the UN Sustainable Development Agenda. They highlight the extent to which customary hospitality and tourism HRM practice at macro and meso levels fails to deliver HRD for much of its workforce; thus, the sector cannot be viewed as providing sustainable employment. One could argue that the cases given in Section 3 indicate isolated examples of bad practice in specific locations, yet the literature supports our assertion that, in general, hospitality and tourism HRM operates contrary to the principles of sustainable HRM explained in Section 1 . The point being made by this paper is not that critical research about the pervasive lack of decent work opportunities in the tourism sector is lacking, but that tourism institutions, the tourism academy and tourism organizations are unwilling to commit to changing the status quo. The themes covered in this paper effectively illustrate the risks associated with overlooking the importance of this neglected area within the wider sustainable tourism narrative.

Author Contributions: Tom Baum: paper concept, literature review, conclusions. Shelagh Mooney: section on gender, support for concept and conclusions. Sridar and May Ling: section on social entrepreneurship. Haiyan Kong: section on careers. Marinela Dropulić Ružić: section on generational perspectives. Anna Kralj: mobilities. Hải Nguyễn Thị Thanh: human rights. Catherine Cheung: education.

Conflicts of Interest: The authors declare no conflict of interest. The founding sponsors had no role in the design of the study; in the collection, analyses or interpretation of data; in the writing of the manuscript; nor in the decision to publish the results.

\section{References}

1. Wood, R. Working in Hotels and Catering, 2nd ed.; International Thomson: London, UK, 1997.

2. Lucas, R.; Deery, M. Significant developments and emerging issues in human resource management. Int. J. Hosp. Manag. 2004, 23, 459-472. [CrossRef]

3. Baum, T. Human resources in tourism: Still waiting for change. Tour. Manag. 2007, 28, 1383-1399. [CrossRef]

4. Baum, T. Human resources in tourism: Still waiting for change?-A 2015 reprise. Tour. Manag. 2015, 50, 204-212. [CrossRef]

5. Kusluvan, S.; Kusluvan, Z.; Ilhan, I.; Buyruk, L. The human dimension: A review of human resource management issues in the tourism and hospitality industry. Cornell Hosp. Quart. 2010, 51, 171-214. [CrossRef]

6. Baum, T.; Kralj, A.; Robinson, R.; Solnet, D. Tourism workforce research: A review, taxonomy and agenda. Ann. Tour. Res. 2016, 60, 1-22. [CrossRef]

7. Solnet, D.; Nickson, D.; Robinson, R.; Kralj, A.; Baum, T. Discourse about workforce development in tourism-An analysis of public policy, planning, and implementation in Australia and Scotland: Hot air or making a difference? Tour. Anal. 2014, 19, 609-623. [CrossRef]

8. Weaver, D. Can sustainable tourism survive climate change? J. Sustain. Tour. 2011, 19, 5-15. [CrossRef]

9. Miller, G.; Rathouse, K.; Scarles, C.; Holmes, K.; Tribe, J. Public understanding of sustainable tourism. Ann. Tour. Res. 2010, 37, 627-645. [CrossRef]

10. Torres-Delgado, A.; López Palomeque, F. The growth and spread of the concept of sustainable tourism: The contribution of institutional initiatives to tourism policy. Tour. Manag. Perspect. 2012, 4, 1-10. [CrossRef]

11. Edgell, D. International sustainable tourism policy. Brown J. World Aff. 2015, XXII, 25-36.

12. Maxim, C. Drivers of success in implementing sustainable tourism policies in urban areas. Tour. Plan. Dev. 2015, 12, 37-47. [CrossRef]

13. Saarinen, J. Traditions of sustainability in tourism studies. Ann. Tour. Res. 2006, 33, 1121-1140. [CrossRef]

14. Yasarata, M.; Altinay, L.; Burns, P.; Okumus, F. Politics and sustainable tourism development-Can they co-exist? Voices from North Cyprus. Tour. Manag. 2010, 31, 345-356. [CrossRef]

15. Buckley, R. Sustainable tourism: Research and reality. Ann. Tour. Res. 2012, 39, 528-546. [CrossRef]

16. Global Sustainable Tourism Council. Criteria for Destinations: Criteria for Hotels and Tour Operators. Available online: https://www.gstcouncil.org/en/gstc-criteria/criteria-for-destinations.html (accessed on 28 May 2016).

17. International Labour Organization (ILO). Decent Work Indicators. Concepts and Definitions; ILO: Geneva, Switzerland, 2012. 
18. United Nations. Transforming our World: The 2030 Agenda for Sustainable Development. 2015. Available online: https://sustainabledevelopment.un.org/content/documents/21252030\%20Agenda\% 20for\%20Sustainable\%20Development\%20web.pdf (accessed on 10 May 2016).

19. Ehnert, I.; Harry, W. Recent developments and future prospects on sustainable human resource management: Introduction to the Special Issue. Manag. Rev. 2012, 23, 221-238.

20. Jithendran, K.J.; Baum, T. Human resources development and sustainability-The case of Indian tourism. Int. J. Tour. Res. 2000, 2, 403-421. [CrossRef]

21. Zaugg, R.J.; Blum, A.; Thom, N. Sustainability in human resource management, Evaluation Report. 2001. Available online: https://www.empiricon.ch/assets/Publikationen/Personalmanagement/03.5EN-sustainability-in-hrm-200106.pdf (accessed on 12 August 2016).

22. Mazur, B. Managing bicultural organizations in Podlasie region. In Studia z Zarzadzania Międzykulturowego; Sułkowski, L., Waniek, K., Eds.; SWSPiZ: Łódź, Poland, 2009; pp. 295-304.

23. Liebowitz, J. The role of HR in achieving a sustainability culture. J. Sustain. Dev. 2010, 3, 4. [CrossRef]

24. Avery, G. Leadership for Sustainable Futures: Achieving Success in a Competitive World; Edward Elgar Publishing: Cheltenham, UK, 2005.

25. Dunphy, D.C.; Griffiths, A.; Benn, S. Organizational Change for Corporate Sustainability: A Guide for Leaders and Change Agents of the Future; Routledge: London, UK, 2007.

26. Kramar, R. Beyond strategic human resource management: Is sustainable human resource management the next approach? Int. J. Hum. Resour. Manag. 2014, 25, 1069-1089. [CrossRef]

27. Baum, T. Managing Human Resources in the European Tourism and Hospitality Industry: A Strategic Approach; Chapman \& Hall Ltd.: London, UK, 1995.

28. Baum, T. Human Resource Management for Tourism, Hospitality and Leisure, an International Perspective; Thomson Learning: London, UK, 2006; Volume 1.

29. Boardman, J.; Johns, A.; Petre, D. Sectoral Studies on Decent Work in Global Supply Chains: Tourism; Sectoral Studies: Comparative Analysis; International Labour Office: Geneva, Switzerland, 2015; pp. 43-101.

30. Baum, T. International Perspectives on Women and Work in Hotels, Catering and Tourism; Working Paper No. 1/2013; International Labour Organisation: Geneva, Switzerland, 2013; pp. 1-77.

31. Clevenger, L.; Singh, N. Exploring barriers that lead to the glass ceiling effect for women in the U.S. hospitality industry. J. Hum. Resour. Hosp. Tour. 2013, 12, 376-399. [CrossRef]

32. Santero-Sanchez, R.; Segovia-Pérez, M.; Castro-Nuñez, B.; Figueroa-Domecq, C.; Talón-Ballestero, P. Gender differences in the hospitality industry: A job quality index. Tour. Manag. 2015, 51, 234-246. [CrossRef]

33. Statistics New Zealand. Women at Work: 1991-2013; Ministry for Women: Wellington, New Zealand, 2015.

34. Holvino, E. Intersections: The simultaneity of race, gender and class in organization studies. Gend. Work Org. 2010, 17, 248-277. [CrossRef]

35. Parker, J.; Arrowsmith, J. Are we being served? Women in New Zealand's service sector. Equal. Divers. Incl. Int. J. 2012, 31, 663-680. [CrossRef]

36. Mooney, S.; Ryan, I. A woman's place in hotel management: Upstairs or downstairs? Gend. Manag. Int. J. 2009, 24, 195-210. [CrossRef]

37. Poulston, J. Ethical Issues and Workplace Problems in Commercial Hospitality: A New Zealand Study; Auckland University of Technology: Auckland, New Zealand, 2006.

38. Mooney, S. How the Intersections of Age, Gender, Ethnicity and Class Influence the Longevity of a Hospitality Career in New Zealand. Ph.D. Thesis, Auckland University of Technology, Auckland, New Zealand, 2014. Available online: http:/ / aut.researchgateway.ac.nz/handle/10292/7486 (accessed on 1 August 2014).

39. Williams, C. The glass escalator, revisited gender inequality in neoliberal times. Gend. Soc. 2013. [CrossRef]

40. Statistics New Zealand. Tourism Sector Report 2013 (MBIE). Available online: http:/ /www.tourism2025.org. nz/2025-in-depth/tourism-sector-report-2013-mbie/ (accessed on 28 July 2016).

41. Solnet, D.; Kralj, A.; Baum, T. 360 degrees of pressure: The changing role of the HR professional in the hospitality industry. J. Hosp. Tour. Res. 2015, 39, 271-292. [CrossRef]

42. Williamson, D.; Harris, C.; Ravenswood, K. The Cinderella makeover: New Zealand hotels as an "industry" versus New Zealand hotels as "work". In AIRAANZ Conference 2015 Book of Abstracts; Lloyd-Hagemann: Auckland, New Zealand, 2015; p. 116. 
43. Waldegrave, C. Living Wage Aotearoa New Zealand; Family Centre Social Policy Research Unit: Wellington, New Zealand, 2016; p. 1. Available online: http://www.livingwage.org.nz/reports_and_research (accessed on 5 April 2016).

44. NZNews. Masala Bosses Sentenced for Worker Exploitation, 3News Report. 2015. Available online: http:/ / www.newshub.co.nz/nznews/masala-bosses-sentenced-for-worker-exploitation-2015101612\# axzz4FeTnJkXA (accessed on 28 July 2016).

45. Flynn, S.; Harris, M. Mothers in the New Zealand workforce. In Proceedings of the the LEW16 Conference, Wellington, New Zealand, 27-28 November 2014; Available online: http:/ /www.stats.govt.nz (accessed on 29 July 2016).

46. Bohle, P.; Quinlan, M.; Kennedy, D.; Williamson, A. Working hours, work-life conflict and health in precarious and "permanent" employment. Rev. Saúde Públ. 2004, 38, 19-25. [CrossRef]

47. Deery, M.; Jago, L. Revisiting talent management, work-life balance and retention strategies. Int. J. Contemp. Hosp. Manag. 2015. [CrossRef]

48. McPhail, R.; Patiar, A.; Herington, C.; Creed, P.; Davidson, M. Development and initial validation of a hospitality employees' job satisfaction index: Evidence from Australia. Int. J. Contemp. Hosp. Manag. 2015. [CrossRef]

49. Mooney, S.; Harris, C.; Ryan, I. Long hospitality careers-A contradiction in terms? Int. J. Contemp. Hosp. Manag. 2016. in press.

50. Luo, Y.; Milne, S. Current human resource management practices in the New Zealand hotel sector. J. Hum. Res. Hosp. Tour. 2013, 13, 81-100. [CrossRef]

51. Urry, J. Mobile sociology. Br. J. Soc. 2000, 51, 185-203. [CrossRef]

52. Duncan, T.; Scott, D.; Baum, T. The mobilities of hospitality work: An exploration of issues and debates. Ann. Tour. Res. 2013, 41,1-19. [CrossRef]

53. Robinson, R.N.S.; Ritchie, B.W.; Kralj, A.; Solnet, D.S.; Baum, T.; Ford, R. An Asia-Pacific core-periphery futures paradox: Divergent worker and tourist mobilities. J. Travel Res. 2014, 53, 805-818. [CrossRef]

54. Lund-Durlacher, D.; Dimanche, F. Mobilities and sustainable tourism: An introduction. J. Sustain. Tour. 2016, 24, 505-637. [CrossRef]

55. Dredge, D.; Jamal, T. Mobilities on the Gold Coast, Australia: Implications for destination governance and sustainable tourism. J. Sustain. Tour. 2013, 21, 557-579. [CrossRef]

56. United Nations World Tourism Organization (UNWTO). UNWTO Tourism Highlights: 2015 Edition; UNWTO: Madrid, Spain, 2015.

57. United Nations (UN). World Urbanization Prospects: The 2014 Revision, Highlights; United Nations: New York, NY, USA, 2014.

58. Urry, J.; Larsen, J. The Tourist Gaze 3.0; Sage: London, UK, 2011.

59. Turner, L.; Ash, J. The Golden Hordes: International Tourism and the Pleasure Periphery; Constable: London, UK, 1975.

60. Baum, T. Demographic changes and the labour market in the international tourism industry. In Tourism and Demography; Yeoman, I., Hsu, C., Smith, K., Watson, S., Eds.; Goodfellow: London, UK, 2010; pp. 179-194.

61. Gogia, N. Unpacking corporeal mobilities: The global voyages of labour and leisure. Environ. Plan. 2006, 38, 359-375. [CrossRef]

62. Bianchi, R. Migrant tourist-workers: Exploring the 'contact zones' of post-industrial tourism. Curr. Issues Tour. 2000, 3, 107-137. [CrossRef]

63. Carson, D.A.; Carson, D.B.; Lundmark, L. Tourism and Mobilities in Sparsely Populated Areas: Towards a Framework and Research Agenda. Scand. J. Hosp. Tour. 2014, 14, 353-479. [CrossRef]

64. Solnet, D.; Hood, A. Generation Y as hospitality employees: Framing a research agenda. J. Hosp. Tour. Manag. 2008, 15, 59-68. [CrossRef]

65. Cresswell, T. Towards a politics of mobility. Environ. Plan. D 2010, 28, 17-31. [CrossRef]

66. Janta, H.; Brown, L.; Lugosi, P.; Ladkin, A. Migrant relationships and tourism employment. Ann. Tour. Res. 2011, 38, 1322-1343. [CrossRef]

67. Lundmark, L.; Ednarsson, M.; Karlsson, S. International migration, self-employment and restructuring through tourism in sparsely populated areas. Scand. J. Hosp. Tour. 2014, 14, 422-440. [CrossRef]

68. Solnet, D.; Ford, R.; Robinson, R.N.S.; Ritchie, B.W.; Olsen, M. Locational factors for tourism employment. Ann. Tour. Res. 2014, 45, 30-45. [CrossRef] 
69. Cooper, C.; Ruhanen, L. The Tourism Labour Market in the Asia-Pacific Region; World Tourism Organization (UNWTO): Madrid, Spain, 2009.

70. Solnet, D.; Baum, T.; Kralj, A.; Robinson, R.N.S.; Ritchie, B.W.; Olsen, M. The Asia-Pacific tourism workforce of the future: Using Delphi techniques to identify possible scenarios. J. Travel Res. 2014, 53, 693-704. [CrossRef]

71. Bookman, M.Z. Tourists, Migrants and Refugees; Lynne Rienner Publishers: Boulder, CO, USA, 2006.

72. Park, J.; Gursoy, D. Generation effects on work engagement among US hotel employees. Int. J. Hosp. Manag. 2012, 31, 1195-1202. [CrossRef]

73. Gursoy, D.; Chi, C.G.Q.; Karadag, E. Generational differences in work values and attitudes among frontline and service contact employees. Int. J. Hosp. Manag. 2013, 32, 40-48. [CrossRef]

74. Lu, A.C.C.; Gursoy, D. Impact of job burnout on satisfaction and turnover intention: Do generational differences matter? J. Hosp. Tour. Res. 2013. [CrossRef]

75. Chen, P.J.; Choi, Y. Generational differences in work values: A study of hospitality management. Int. J. Contemp. Hosp. Manag. 2008, 20, 595-615. [CrossRef]

76. Solnet, D.; Kralj, A. Generational differences in work attitudes: Evidence from the hospitality industry. Hosp. Rev. 2011, 29, Article 3.

77. Gursoy, D.; Maier, T.A.; Chi, C.G. Generational differences: An examination of work values and generational gaps in the hospitality workforce. Int. J. Hosp. Manag. 2008, 27, 448-458. [CrossRef]

78. Maier, T.A. Hospitality leadership implications: Multigenerational perceptions of dissatisfaction and intent to leave. J. Hum. Res. Hosp. Tour. 2011, 10, 354-371. [CrossRef]

79. Solnet, D.; Kralj, A.; Kandampully, J. Generation Y employees: An examination of work attitude differences. J. Appl. Manag. Entrep. 2012, 17, 36-54.

80. Chi, C.G.; Maier, T.A.; Gursoy, D. Employees' perceptions of younger and older managers by generation and job category. Int. J. Hosp. Manag. 2013, 34, 42-50. [CrossRef]

81. Zopiatis, A.; Krambia-Kapardis, M.; Varnavas, A. Y-ers, X-ers and Boomers: Investigating the multigenerational (mis) perceptions in the hospitality workplace. Tour. Hosp. Res. 2012, 12, 101-121. [CrossRef]

82. Lub, X.; Nije Bijvank, M.; Matthijs Bal, P.; Blomme, R.; Schalk, R. Different or alike? Exploring the psychological contract and commitment of different generations of hospitality workers. Int. J. Contemp. Hosp. Manag. 2012, 24, 553-573. [CrossRef]

83. Maier, T.; Tavanti, M.; Bombard, P.; Gentile, M.; Bradford, B. Millennial generation perceptions of value-centered leadership principles. J. Hum. Res. Hosp. Tour. 2015, 14, 382-397. [CrossRef]

84. Chuang, N.K.; Goh, B.K.; Stout, B.L.; Dellmann-Jenkins, M. Hospitality undergraduate students' career choices and factors influencing commitment to the profession. J. Hosp. Tour. Ed. 2007, 19, 28-37. [CrossRef]

85. Richardson, S.; Thomas, N.J. Utilising generation Y: United States hospitality and tourism students' perceptions of careers in the industry. J. Hosp. Tour. Manag. 2012, 19, 102-114. [CrossRef]

86. Maxwell, G.A.; Ogden, S.M.; Broadbridge, A. Generation Y's career expectations and aspirations: Engagement in the hospitality industry. J. Hosp. Tour. Manag. 2010, 17, 53-61. [CrossRef]

87. Richardson, S. Generation Y's perceptions and attitudes towards a career in tourism and hospitality. J. Hum. Res. Hosp. Tour. 2010, 9, 179-199. [CrossRef]

88. Josiam, B.M.; Devine, F.G.; Baum, T.; Crutsinger, C.; Reynolds, J.S. Attitudes to work of Generation Y students in hospitality management: A comparative analysis of students in England, Scotland and Northern Ireland. J. Hosp. Tour. Ed. 2010, 22, 44-53. [CrossRef]

89. Josiam, B.M.; Reynolds, J.S.; Thozhur, S.; Crutsinger, C.; Baum, T.; Devine, F.G. Attitudes to work of Generation Y students in hospitality management: A comparative analysis of students in the United States and the United Kingdom. J. Foodserv. Bus. Res. 2008, 11, 295-314. [CrossRef]

90. Richardson, S. Undergraduates' perceptions of tourism and hospitality as a career choice. Int. J. Hosp. Manag. 2009, 28, 382-388. [CrossRef]

91. Lu, T.; Adler, H. Career goals and expectations of hospitality and tourism students in China. J. Teach. Travel Tour. 2009, 9, 63-80. [CrossRef]

92. Kim, S.H.; Kim, M.; Han, H.S.; Holland, S. The determinants of hospitality employees' pro-environmental behaviors: The moderating role of generational differences. Int. J. Hosp. Manag. 2016, 52, 56-67. [CrossRef] 
93. Inelmen, K.; Zeytinoglu, I.U.; Uygur, D. Are Millennials a different breed? Turkish hospitality sector frontline employees' intention to stay. In Managing the New Workforce: International Perspectives on the Millennial Generation; Edward Elgar: Cheltenham, UK, 2012; pp. 181-203.

94. Parry, E.; Urwin, P. Generational differences in work values: A review of theory and evidence. Int. J. Manag. Rev. 2011, 13, 79-96. [CrossRef]

95. Lyons, S.; Kuron, L. Generational differences in the workplace: A review of the evidence and directions for future research. J. Org. Behav. 2014, 35, S139-S157. [CrossRef]

96. Lee, C.; Way, K. Individual employment characteristics of hotel employees that play a role in employee satisfaction and work retention. Int. J. Hosp. Manag. 2010, 29, 344-353. [CrossRef]

97. Brown, E.A.; Thomas, N.J.; Bosselman, R.H. Are they leaving or staying: A qualitative analysis of turnover issues for Generation Y hospitality employees with a hospitality education. Int. J. Hosp. Manag. 2015, 46, 130-137. [CrossRef]

98. McCabe, V.S.; Savery, L.K. "Butterflying" a new career pattern for Australia? Empirical evidence. J. Mgmt. Dev. 2007, 26, 103-116. [CrossRef]

99. Kong, H.; Cheung, C.; Song, H. From hotel career management to employees' career satisfaction-The mediating effect of career competencies. Int. J. Hosp. Manag. 2012, 31, 76-85. [CrossRef]

100. Deery, M. Talent management, work-life balance and retention strategies. Int. J. Contemp. Hosp. Manag. 2008, 20, 792-806. [CrossRef]

101. Kong, H. Relationships among work-family supportive supervisors, career competencies, and job involvement. Int. J. Contemp. Hosp. Manag. 2013, 33, 304-309. [CrossRef]

102. Bharwani, S.; Jauhari, V. An exploratory study of competencies required to co-create memorable customer experiences in the hospitality industry. Int. J. Contemp. Hosp. Manag. 2013, 25, 823-843. [CrossRef]

103. Kong, H.; Yan, Q. The relationship between learning satisfaction and career competencies. Int. J. Hosp. Manag. 2014, 41, 133-139. [CrossRef]

104. Bratton, J.; Gold, J. Towards Critical Human Resource Management Education (CHRME): A sociological imagination approach. Work Employ. Soc. 2015, 29, 496-507. [CrossRef]

105. Dempsey, N.; Bramley, G.; Power, S.; Brown, C. The social dimensions of sustainable development: Defining urban social sustainability. Sustain. Dev. 2011, 19, 289-300. [CrossRef]

106. Stoddard, J.; Pollard, C.; Evans, M. The triple bottom line: A framework for sustainable tourism development. Int. J. Hosp. Tour. Admin. 2012, 13, 233-258. [CrossRef]

107. Giacalone, R.; Thompson, K. Business ethics and social responsibility education: Shifting the worldview. Acad. Manag. Learn Ed. 2006, 5, 266-277. [CrossRef]

108. Neubaum, D.; Pagell, M.; Drexler, J.; McKee-Ryan, F.; Larson, E. Business education and its relationship to student personal moral philosophies and attitudes toward profits: An empirical response to critics. Acad. Manag. Learn. Ed. 2009, 8, 9-24. [CrossRef]

109. Wade, R.; Parker, J. EFA-ESD Dialogue: Educating for a Sustainable World. UNESCO. 2008. Available online: http:/ / unesdoc.unesco.org/images/0017/001780/178044e.pdf (accessed on 22 July 2016).

110. Malovics, G.; Csignene, N.N.; Kraus, S. The role of corporate social responsibility in strong sustainability. J. Socio-Econ. 2008, 37, 907-918. [CrossRef]

111. Wade, J. Students as environmental change agents. Int. J. Contemp. Hosp. Manag. 1999, 1, 251-255. [CrossRef]

112. Deale, C.; Barber, N. How important is sustainability education to hospitality programs? J. Teach. Travel Tour. 2012, 12, 165-187. [CrossRef]

113. Millar, M.; Park, S.Y. Sustainability in hospitality education: The industry's perspective and implications for curriculum. J. Hosp. Tour. Ed. 2013, 25, 80-88. [CrossRef]

114. Archer, B.; Cooper, C.; Ruhanen, L. The positive and negative impacts of tourism. In Global Tourism; Theobold, W.F., Ed.; Elsevier: New York, NY, USA, 2005; pp. 79-102.

115. Yang, H.J.; Cheung, C. What types of experimental learning activities can engage hospitality students in Asia? J. Hosp. Tour. Ed. 2012, 24, 21-27.

116. Isacsson, A.; Gretzel, U. Facebook as an edutainment medium to engage students in sustainability and tourism. J. Hosp. Tour. Technol. 2011, 2, 81-90. [CrossRef]

117. Paula, J.; Selby, D.; Sterling, S. Sustainability Education: Perspectives and Practice across Higher Education; Earthscan: London, UK, 2010.

118. Parker, J. Increasing industry demand for triple bottom line education. Consort. J. Hosp. Tour. 2011, 16, 47-50. 
119. Von der Weppen, J.; Cochrane, J. Social enterprises in tourism: An exploratory study of operational models and success factors. J. Sustain. Tour. 2012, 20, 497-511. [CrossRef]

120. Christoph, G.; Laeis, M.; Lemke, S. Social entrepreneurship in tourism: Applying sustainable livelihoods approaches. Int. J. Contemp. Hosp. Manag. 2016, 28. [CrossRef]

121. Mottiar, Z. Exploring the motivations of tourism social entrepreneurs. Int. J. Contemp. Hosp. Manag. $2016,28$. [CrossRef]

122. Peng, K.L.; Lin, P.M.C. Social entrepreneurs: Innovating rural tourism through the activism of service science. Int. J. Contemp. Hosp. Manag. 2016, 28. [CrossRef]

123. Wang, C.L.; Duan, Z.; Yu, L. From non-profit organization to social enterprise: The paths and future of a Chinese social enterprise in the tourism field. Int. J. Contemp. Hosp. Manag. 2016, 28. [CrossRef]

124. Tinsley, R.; Lynch, P.A. Small business networking and tourism destination development: A comparative perspective. Int. J. Entrep. Innov. 2007, 8, 15-27. [CrossRef]

125. Ho, J.A.; Chia, K.W.; Ng, S.I.; Ramachandran, S. Problems and stakeholder responsibilities in island tourism: The case of Tioman Island, Malaysia. J. Hosp. Tour. Res. 2013. [CrossRef]

126. Siow, M.L.; Ramachandran, S.; Shuib, A.; Afandi, S.H.M. Barriers to community participation in rural tourism: A case study of the communities of Semporna, Sabah. Life Sci. J. 2014, 11, 837-841.

127. Ibrahim, M.R.; Shuib, A.; Ramachandran, S.; Afandi, S.H. A sustainable community based tourism enterprises through Amanah Ikhtiar Malaysia in Semporna, Sabah: Opportunities and challenges. In Proceedings of the International Conference on Natural Resources, Tourism and Services Management 2015, Sabah, Malaysia, 15-17 April 2015; Ling, S.M., Nair, M.B., Shuib, A., Eds.; Universiti Putra Malaysia: Serdang, Malaysia, 2015; pp. 190-199.

128. Keliher, F.; Foley, A.; Frampton, A.M. Facilitating small firm learning networks in the Irish tourism sector. Tour. Hosp. Res. 2009, 9, 80-95. [CrossRef]

129. Reinl, L.; Keliher, F. Transforming tourism micro firm practitioner learning: Exploring the road to a sustainable learning community. J. Teach. Travel Tour. 2015, 15, 278-293. [CrossRef]

130. Myanmar Centre for Responsible Business (MCRB); Danish Institute for Human Rights (DIHR); Institute for Human Rights and Business (IHRB). Myanmar Tourism Sector Wide Impact Assessment; MCRB: Yangon, Myanmar; DIHR: Copenhagen, Denmark; IHRB: London, UK, 2015.

131. Institute for Human Rights and Business (IHRB). Striving for Excellence: Mega-Sporting Events and Human Rights; IHRB: London, UK, 2013.

132. Dodds, R.; Joppe, M. CSR in the Tourism Industry? The Status of and Potential for Certification, Codes of Conduct and Guidelines; The World Bank: Washington, DC, USA, 2005.

133. Ladkin, A. Exploring tourism labor. Ann. Tour. Res. 2011, 38, 1135-1155. [CrossRef]

134. International Labour Organization (ILO). Accelerating Actions against Child Labour, Global Report under the Follow-up to the ILO Declaration on Fundamental Principles and Rights at Work; ILO: Geneva, Switzerland, 2010.

135. International Labour Organization (ILO). Draft ILO guidelines on Decent Work and Social Responsibility in Tourism; ILO: Geneva, Switzerland, 2015.

136. Getz, D.; Carlsen, J.; Morrison, A. The Family Business in Tourism and Hospitality; CABI: Wallingford, UK, 2004.

137. Admassie, A. Child labor in the context of a subsistence rural economy: Can they be compatible? Int. J. Ed. Dev. 2003, 23, 167-185. [CrossRef]

138. Robson, E. Invisible carers: Young people in Zimbabwe's home-based healthcare. Area 2000, 32, 59-69. [CrossRef]

139. International Labour Organization/IPEC. Give Girls A Chance: Tackling Child Labour, A Key to the Future; ILO: Geneva, Switzerland, 2009.

140. UNICEF. Child Labour-Are Girls Affected Differently to Boys? 2007. Available online: http://www.unicef. org/sowc07/docs/sowc07_panel_3_3.pdf (accessed on 24 November 2015).

141. Ireland, K. Wish You Weren't here: The Sexual Exploitation of Children and the Connection with Tourism and International Travel; Save the Children: London, UK, 1993.

142. Beauttah, B.W.; Rhova, H.M.; Waweru, S. Child Labour in Tourism: A Case in Kilifi, Mombasa and Kwale Districts in the Coast Province of Kenya; ILO-IPEC: Nairobi, Kenya, 1995.

143. Black, M. In the Twilight Zone: Child Workers in the Hotel, Tourism and Catering Industry; ILO: Geneva, Switzerland, 1995.

144. ECPAT. Tourism and Children in Prostitution: Fact Sheet; ECPAT: Bangkok, Thailand, 1995. 
145. Gust, G. Child labour in the hotel, catering and tourism sector. In Presentation during the Tripartite Meeting on the Effects of New Technologies on Employment and Working Conditions in the Hotel, Catering and Tourism Sector; ILO-IPEC: Geneva, Switzerland, 1997.

146. Plüss, C. Quick Money-Easy Money? A Report on Child Labour in Tourism; Arbeitskreis Tourismus \& Entwicklung: Basel, Switzerland, 1999; Available online: http://www.akte.ch/uploads/media/Quick_ money_easy_money.pdf (accessed on 26 July 2015).

(C) 2016 by the authors; licensee MDPI, Basel, Switzerland. This article is an open access article distributed under the terms and conditions of the Creative Commons Attribution (CC-BY) license (http://creativecommons.org/licenses/by/4.0/). 